\title{
Two Questions of SHRM in Literature: Moderators of HRM-Firm Performance Link
}

\author{
Gurhan Uysal \\ Ondokuz Mayıs University, Samsun, Turkey
}

\begin{abstract}
This paper aims to discuss differences between human resource management (HRM) and strategic human resource management (SHRM), and aims to discuss convergence or divergence between American and European HRM. Therefore, research question is what the similarities and differences are between European and American HRM. Research methodology is based on critical review of HRM literature. Therefore, this study aims to increase conceptual ability of human resource (HR) professionals. Major result is that HRM is related with employee performance, and SHRM is related with firm performance. Secondly, European HRM is becoming similar to American HRM. The difference between European and American HRM is social context and social partners. European HRM considers social partners in management of HR.
\end{abstract}

Keywords: human resource (HR) methods, European human resource management (HRM), American HRM, convergence, divergence

\section{Introduction}

Management of human resources started with industrial age after establishing big firms, and scientific management of HR began with Frederick W. Taylor (Uysal, 2012). He advised to practice some personnel management techniques to firms. There are three HR methods in firms to manage human resource-related issues. They are personnel management (PM), human resource management (HRM), and strategic human resource management (SHRM). Focus of those methods is different but they complete each other in firms to manage HR. PM focuses on organizational jobs. It aims to increase efficiency of jobs in firms to increase organizational performance. HRM focuses on employees. It aims to increase employee efficiency to enhance performance of business departments and firm performance. SHRM focuses on firm. It aims to increase firm performance through HRM practices (see Figure 1).

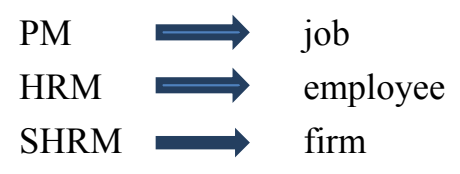

Figure 1. HR methods.

HRM concept is developed in USA in 1960s and 1970s. Therefore, HRM is American concept. So, HRM is spreading in global economies by American multinational corporations (MNCs) and foreign direct

Gürhan Uysal, Ph.D., Associate Professor, School of Business, Ondokuz Mayıs University.

Correspondence corcerning this article should be addressed to Gürhan Uysal, Ondokuz Mayis University, School of Business, Kurupelit Campus, 55139, Samsun, Turkey. E-mail: gurhan.uysal@yahoo.com. 
investment (FDI). Because American headquarters insist on applying home country practices in HRM. However, there are convergence and divergence between American and European HRM. Therefore, this study aims to discuss HR methods, and American and European HRM.

HR practitioners may call human resources in SHRM as capital. Practitioners call human resources as personnel in PM, and as employee in HRM. Individual performance of employees is important to achieve firm performance in SHRM. Therefore, employees are perceived as intellectual capital or human capital to increase firm performance. Because it is expected that intellectual or human capital increases performance of individuals. Human capital can be defined with employee's knowledge and experience in their field. Therefore, organizational learning is accepted as a SHRM practice in firms. Because it is related with human capital or intellectual capital. Organizational learning increases knowledge of employees. Organizational learning is that employees learn occupational knowledge in their career field.

First article of SHRM is published in 1981 in Organizational Dynamics Journal. Then numerous articles are published in academic journals about SHRM. However, those articles become theoretical. Articles do not have hypotheses and so, are not practical for firms. If firms apply SHRM in their organizations, academic researchers establish hypotheses in their research. Firms do not have SHRM departments and managers. Firms may apply interrelated HRM practices and HR systems in their organizations to practice SHRM.

\section{Two Questions of SHRM in Literature}

There are two questions in literature related with SHRM:

(1) How does HRM have an impact on firm performance? What are the moderators between HRM and firm performance?

(2) How can SHRM be put into practice? How do HR practitioners apply SHRM in organizations?

First of all, moderators in HRM-firm performance link are positive organizational attitude and behaviours, individual performance, and business departments. Positive attitudes and behaviours are important in American HRM. American style of HRM aims to develop positive organizational attitude and behaviours in employees so that employees work for organizational goals.

Those moderators also describe theory of HRM in this study (see Figure 2).

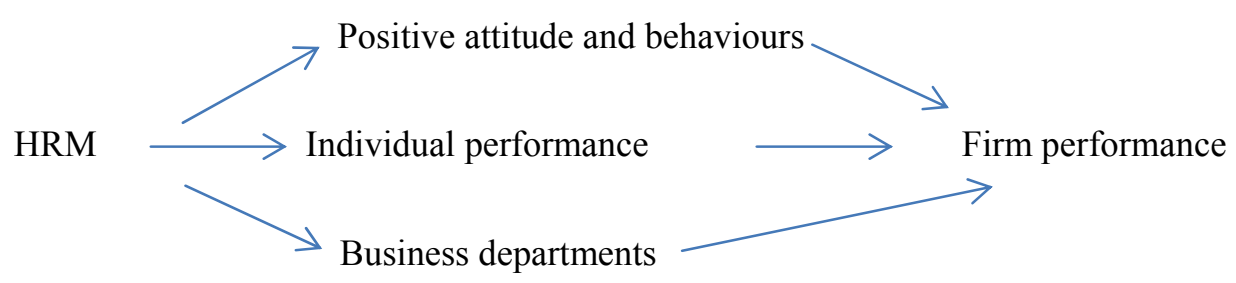

Figure 2. HRM and firm performance link-moderators.

In this model, HRM practices lead to positive organizational attitude and behaviours in employee side. Those attitudes and behaviours are commitment behaviour, motivation, trust, citizenship, satisfaction, absenteeism etc.. Positive attitude and behaviours increase individual performance to which it is very important in American HRM. Therefore, American HRM aims to increase positive attitudes and behaviours in employees to increase their performance. This is the theory of HRM in this study, which is that applying HRM practices results in positive organizational attitude and behaviours; and positive attitude and behaviours increase individual performance. 
Secondly, SHRM can be put into practice by establishing SHRM departments in organizations. HRM departments apply traditional HRM practices. However, SHRM departments apply modern HRM practices such as performance management, human capital practices, organizational learning, HR governance, HR systems, and interrelated HRM practices. However, role of SHRM departments and managers might be advisory. SHRM departments and managers can be advisor of HRM managers in management of human resources in organizations.

In addition, there is also third question in literature. What is the effect of HRM practices on human resources of firms? Answers might be positive organizational attitude and behaviours. This is the theory of HRM. HRM practices increase positive organizational attitude and behaviours; and positive attitude and behaviours increase individual performance.

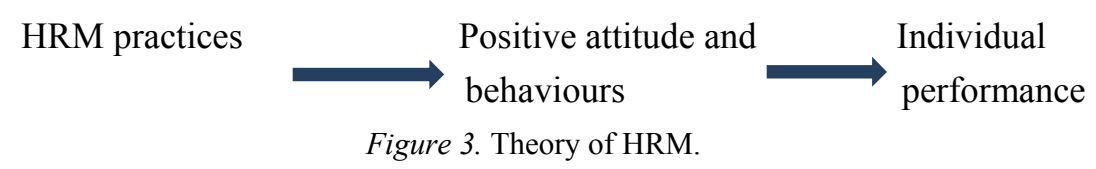

Therefore, firstly, HRM can be defined as applying HRM practices in organizations. Secondly, the theory of HRM is to produce HRM outcomes. Because HR outcomes contribute to achieving firm performance. Most prominent outcome of HRM might be positive organizational attitude and behaviours.

\section{American SHRM: Perspectives of American Scholars in SHRM}

Firstly, American scholars tend to system theory in SHRM. They identify SHRM with HR systems. Major prominent of HR system is interrelated HRM practices. Secondly, American scholars identify SHRM with HRM-firm performance link. Thirdly, American SHRM pays more attention to fit notion in SHRM. Because internal fit is necessary to develop interrelated HRM practices and HR systems, and external fit is necessary to achieve HRM-firm performance link in organizations. Fit is the third dimension in American SHRM. The first one is performance and the second one is HR system. For example, HR system is a mediator between HRM and firm performance, according to a literature study in Indonesian firms. HR system has an impact on individual performance. MacDuffie (1995) suggested HR systems perspective for firms in his article in Industrial and Labor Relations Journal.

Fit is goal congruent of various organizational variables. Individual performance may establish external fit between HRM and firm performance. Because individual performance has an impact on firm performance through business departments. Therefore, individual performance may become external fit tool between HRM and firm performance. Fit perspective is important to establish SHRM in organizations. Because fit develops interrelated HRM practices in firms through internal fit; and fit attaches HRM practices with firm performance through external fit.

Performance management may become internal fit tool. Because performance management is interrelated HRM practices. Performance management is to apply training, compensation, performance appraisal, and carrer planning together to improve employee's individual performance. Therefore, performance management practices can be internal fit tool to establish HR systems and interrelated HRM practices.

In order to become strategic partner HR may establish external fit between HRM and firm performance. HR directors may become strategic partner by having a chair in board of directors in firms. They can influence management decisions in employment decisions such as dismissal, reward, promotion, rotation etc.. If HR has 
an effect on employment decisions, HR becomes strategic partner of firms. Thirdly, HR may become strategic partner of firms by working together with line managers. HR managers may become advisor to line managers in HRM practices. HR managers become advisor to line managers in HRM practices such as performance evaluation, carrer planning, and determining compensation.

Internal fit is to establish interrelated HRM practices in organizations. Interrelated HRM practices can be achieved through understanding correlations between HRM practices. For example, HR managers are to recognize correlation between staffing-training-performance appraisal, and correlation between performance appraisal-promotion-compensation.

Finally, Devanna, Fombrun, and Tichy (1981) defined SHRM with corporate strategy and competitive advantage. Wright and McMahan (1992) defined SHRM with firm performance. Huselid (1995) suggested high performance work systems (HPWS) and HR systems. HPWS has an impact on human capital of employees. Delery and Doty (1996) explained SHRM with "fit" notion. Because HR systems thinking in SHRM requires internal fit and external fit notions. Schuler and Jackson (1987) tend to contextual perspective in SHRM. They say that regulations are context in HRM in contextual perspective. In addition, European scholars put impact of institutional settings on the shaping of HRM. Institutional settings are such as trade unions, work councils, labor legislations and government. Further, Lepak and Snell (2002) advised "human capital". Lepak (2003) said that human capital has an impact on employee and firm performance. Lepak and Snell also discussed "HR architecture" notion. HR architectute is to build HR systems in organizations through interrelated HRM practices.

\section{European SHRM}

European SHRM can be defined with "strategic personnel management". In addition, American SHRM is defined with HRM. Because personnel management is originated in Europe after industrial age. PM is originated in Europe, and HRM is originated in USA. Therefore, European firms have tradition (organizational culture) in personnel management. Therefore, European SHRM might be to apply strategic dimension of personnel management. Strategic PM is that PM has an influence on organizational performance. It is similar to the definiton of SHRM in American literature. It is HRM-firm performance link. PM focuses on jobs in organizations. While HRM focuses on employees. Employees are persons that implement jobs in firms in PM. Therefore, strategic PM may have an impact on firm performance through organizational jobs. On the other hand, HRM has an impact on firm performance through employee performance. In HRM theory, HRM practices have an impact on employee performance and individual performance is expected to increase performance of business departmants and it is expected that performance of business departments increase performance of firm. Similarly, strategic PM can be described with relationship between job performance and firm performance. Job performance can be defined with job outcomes such as customer satisfaction and job efficiency.

PM is interested with job efficiency, HRM is interested with employee efficiency. Major sign of employee efficiency is individual performance. Major sign of job efficicency is to achieve job targets, which are set by managers and departments. If PM has an impact on job efficiency, it gains strategic dimension on firm performance. PM may increase job efficiency via job analysis, job flow chart, job departmentation, on-the-job-training, job definition, and coaching. 


\section{Convergence or Divergence Between European HRM and American HRM ${ }^{1}$}

This part of paper discusses convergence and divergence issue in European and American HRMs. Firstly, American HRM is based on configurational perspective. It makes up HR system in management of HR in firms. For example, Huselid (1995) advocated HPWS, HR systems, and HR architecture in HRM theory. Secondly, American HRM has shareholder perspective. Because USA is shareholder economy. Therefore, American HRM has firm performance targets to provide more value to shareholders. Thirdly, American HRM considers employees as a resource. This is aligned with resource-based theory of Barney (1991).

Firstly, stakeholders are important in European HRM. Therefore, European HRM has stakeholders perspective. Stakeholders are such as involvement of state, institutions, their regulations, trade unions, and social partners. Therefore, European firms consider stakeholders in management of HR. Secondly, European HRM head for adopting American HRM but they have social context and environment. Therefore, European HRM can be formulased as European HRM = American HRM + social context.

Firstly HRM is developing field in Europe. Secondly American MNCs deploy American HRM in European market. Thirdly, European HRM is adopting firm performance target similar to American HRM. Major difference between American and European HRM is state regulations such as regulations in staffing, dismissal, industrial relations. Fourthly, European HRM has contextual perspective - role of state, institutions, trade unions, social partners, labor legislations build social environment in European HRM.

Chris Brewster, Paul Sparrow, A. Hegewisch, Wolfgang Mayrhofer, and Paul Gooderham are leading researchers in Europe in European HRM. Most citations are given to Chris Brewster in European HRM research. Brewster (2007) claimed that there is a European HRM. On the other hand, Sparrow (2004) said that there is "HRM in Europe" notion. European HRM is between American HRM and social context. HRM in Europe concept adopts American HRM practices.

The major difference between American and European HRM is organisational autonomy. American HRM is more autonomous in management of HR. While European HRM is restricted by stakeholders and regulations in HRM. This difference may emerge difference of economic systems in both markets. The USA is liberal market economy, and firms are free in management of HRM. EU economy is coordinated market economy, and EU is regulated economy. Therefore, firms have restrictions in HRM by state and regulations. Because regulated market economy take into consideration social awareness of market outcomes. Finally, firms are autonomous in American HRM to protect state. Americans aim to protect their state; therefore, firms are aoutonomous in HR. However, Europeans aim to protect their society and social rest. Therefore, firms have restrictions in HR.

Convergence between American and European HRM may be achieved through MNCs. Because American MNCs insist of applying headquarter's HRM practices in local subsidiaries. This spread American HRM accross European market. Divergence may be achieved through social context. Because there is economic system difference between two markets. The USA is shareholder economy, and EU is stakeholder economy. EU aims to protect stakeholders. Therefore, they have state interventions, institiutional impact, and regulations in European HRM. To conclude, European HRM is becoming similar to American HRM. Difference is social context. European HRM adopts American HRM practices and European HRM adopts firm performance variations. Finally, Europe is becoming deregulated economy, and firms are becoming autunomous in HR.

\footnotetext{
${ }^{1}$ This part of paper is accepted for presentation at 9th Silkroad International Conference in Tbilisi, Georgia, held by International Black Sea University on May 23-25th, 2014.
} 


\section{Discussion}

There are may be two differences between HRM and SHRM:

(1) HRM is interested with individual performance, and SHRM is interested with firm performance;

(2) HRM practices are individual in HRM, and HRM practices are interrelated in SHRM.

In addition, HRM may be towards shareholder value, and SHRM is towards stakeholder value. HRM has shareholder value because HRM is interested with individual performance. Therefore, individuals are interested with their individual earnings or outcomes. SHRM has stakeholder value because SHRM is interested with firm performance. Because stakeholders of firms are interested with firm performance. Personnel management may also possess stakeholder value because PM focuses on "job" in organizations and jobs have stakeholders in organizations such as employees, customers, peers, and supervisors. All the people will pay attention to the outcome of jobs.

For example, Becker, Huselid, Pickus, and Spratt (1997) studied an article entitled as HR as a Source of Shareholder Value in Human Resource Management Journal. Because the USA is shareholder economy, and the USA economy is based on liberal market view. In liberal economy, entrepreneurs establish firms to earn profit. Therefore, they are interested with organizational results and firm performance such as market share, profit, sales, and growth. Therefore, American HRM has shareholder perspective to provide value to shareholders. For example, American HRM applies individual performance appraisals, reward plans, and career planning in management of HR.

\section{Conclusions}

The major difference between HRM and SHRM is to become efficiency and effectiveness. HRM is efficicency, and SHRM is effectiveness. Efficiency is related with outcome of jobs, and effectiveness is related with organizational goals. HRM aims to increase efficiency of employees in jobs and HRM applies HRM practices to increase efficicency of employees. Major sign of efficiency in jobs is individual performance. SHRM focuses on increasing employee effectiveness so that employees work for achieving organizational objectives.

There are some SHRM phrases by managers in organizations. They are:

- HRM managers must be aware of performance of department managers in firm. Because performance of managers has an impact on firm performance;

- Low turnover rate increases performance of business departments. Business departments which have low turnover rate have $60 \%$ more profit than business departments which have higher turnover rate. Therefore, HRM managers must be aware of turnover rate in their organizations to have an impact on firm performance through business departments and employee performance.

Those phrases are related with performance of business departments in firms such as logistics department, finance department, marketing department, stock department etc., because performance of individuals increases performance of departments, and it has an impact on firm performance. Therefore, HRM theory is crucial to SHRM theory, because, according to HRM theory, HRM practices develop positive organizational attitude and behaviours in employees. Positive organizational attitude and behaviours results in increased individual performance. Aligned with SHRM theory, individual performance has an impact on performance of business departments, and this has an impact on firm performance. Therefore, individual performance and organizational 
attitude and behaviours are crucial in SHRM, Because they have an impact on performance of firm.

How is SHRM put into practice by firms? First of all, organizations may establish SHRM departments, and they can appoint SHRM managers for those departments. Job definitions of SHRM managers are to become advisor to HR managers in firms in employment decisions such as to apply interrelated HRM practices.

One of the duty of HR managers and SHRM managers in firms may be to become advisor to line managers and top managers in employment decisions. HR may become advisior to management in employment decisions such as promotion, transfer, dismissal, wage, and career planning.

To conlude, this paper argues the theory of HRM and the theory of SHRM. The theory of SHRM is that HRM has an impact on firm performance through individual performance and business departments. HRM practices have an impact on individual performance, and individual performance increases performance of business departments, and performance of business departments has an impact on overall firm performance. The theory of HRM is that HRM practices lead to positive organizational attitude and behaviours in employees. and positive attitudes and behaviours have an impact on individual performance. Because HRM is related with individual performance.

Secondly, HR methods are applied together in firms. HR methods are personnel management, human resource management, and strategic human resource management. PM focuses on "job"; HRM focuses on "employees"; and SHRM focuses on "firm". Therefore, none of HR methods are ignored by firms, and should be applied together in firms.

\section{References}

Abbas, R. Z., Rafay, A., Ahmad, Z., \& Kitchlew, N. (2011). An exploratory study of SHRM practices in developing countries: A case of public sector organization GSP. Interdisciplinary Journal of Contemporary Research in Business, 2(11), 43-66.

Alharthey, B. K., \& Rasli, A. (2011). Key role of strategic human resource management (SHRM) in advancing the degree of team learning. African Journal of Business Management, 5(26), 10446-10451.

Alonso, A. (2013). SHRM's HR competency model: A roadmap for building proficiency. Society for Human Resource Management (pp. 1-47).

Aslan, Ö. (2010). HR case study (Bir Insan Kaynakları Masalı) (5th ed.). Ankara, Turkey: Elma Publishing.

Barney, J. B. (1991). Firm resources and sustained competitive advantage. Journal of Management, 17, 99-120.

Baş, T. (2011). Employer branding (İşveren Markası). Istanbul, Turkey: Optimist Publishing.

Becker, B. A., Huselid, M. A., Pickus, P. S., \& Spratt, M. F. (1997). HR as a source of shareholder value: Research and recommmendations. Human Resource Management, 1(36), 39-47.

Becker, B. E., \& Huselid, M. A. (1992). Direct estimates of SD, and the implications for utility analysis. Journal of Applied Psychology, 77(3), 227-233.

Blackman, D., O’Flynn, J., \& Mishra, D. P. (2010). Can strategic human resource management enable gross national happiness? International Journal of Commerce and Management, 20(3), 232-245.

Boselie, P., \& Paauwe, J. (2004). Human resource function competencies in European companies. ERIM Report Series Reference No. ERS-2004-069-ORG.

Boselie, P., Paauwe, J., \& Jansen, P. (2000). Human resource management and performance: Lessons from the Netherlands. ERIM Report Series, ERS-2000-46-ORG, Erasmus Research Institute of Management.

Bowen, D. E., \& Ostroff, C. (2004). Understanding HRM-firm performance linkages: The role of the strength of the HRM system. Academy of Management Review, 29(2), 203-221.

Braun, W. H., \& Warner, M. (2002). Strategic human resource management in western multinationals in China. Personnel Review, 31(5), 553-579.

Brewster, C. (1992). European human resource management: Reflection of, or challenge to, the American concept?. Cranfield, UK: Cranfield School of Management, Cranfield Institute of Technology. 
Brewster, C. (1995a). Industrial relations and human resource management: A subsersive European model. Industrielle Berziehungan, 2(4), 395-413.

Brewster, C. (1995b). Towards a European model of HRM. Journal of International Business Studies, 26(1), 1-21.

Brewster, C. (2007). A European perspective on HRM. European Journal of International Management, 1(3), $239-259$.

Brewster, C., \& Larsen, H. H. (2000). The northern European dimension. In C. Brewster, \& H. H. Larsen (Eds.), Human resource management in northern Europe. Oxford: Blackwell Business.

Burbach, R., \& Royle, T. (2010). Global integration versus local adaptation of E-HRM system in a US MNC. Proceedings from 3rd European Academic Workshop on Electronic Human Resource Management. Bamberg, Germany.

Catalin-Ionut, C. (2012). Different approaches to SHRM and organizational performance. Proceedings from the International Conference Education and Creativity for a Knowledge Based Society-Social and Political Sciences, Communication, Foreign Languages and Public Relations. Titu Maiorescu University, Bucharest, Romania.

Cesyniene, R. (2008). Globalization and human resource management. Ekonomika, 82, 41-56.

Chew, I., \& Goh, M. (1997). Some future directions of human resource practices in Singapore. Career Development International, 2(5), 238-244.

Claus, L. (2003). Similarities and difference in human resource management in the European Union. Thunderbird International Business Review, 45(6), 729-755.

Colbert, B. A. (2004). The complex resource-based view: Implications for theory and practice in strategic human resource management. Academy of Management Review, 29(3), 341-358.

Damer, D. (2002). The Japanese vs. the European approach to human resource management in China. MCD Term Paper, Research Paper.

De Pablos, P. O. (2004). Human resource management systems and their role in the development of strategic resources: Empirical evidence. Journal of European Industrial Training, 28(6), 474-489.

Delery, J. E., \& Doty, D. H. (1996). Modes of theorizing in strategic human resource management: Tests of universalistic, contingency and configurational performance predictions. Academy of Management Journal, 39(4), 802-835.

Devanna, M. A., Fombrun, C., \& Tichy, N. (1981). Human resource management: A strategic perspective. Organizational Dynamics, 9(3), 51-68.

Elliot, H. G. (2003). SHRM best-practices \& sustainable competitive advantage: A resource-based view. Retrieved from http://www.business.otago.ac.nz/mgmt/publications/omgr/2003/03elliott1.pdf

Fenton-O'Creevy, M., Gooderham, P., \& Nordhaug, O. (2008). Human resource management in US subsidiaries in Europe and Australia: Centralisation or automomy?. Journal of International Business Studies, 39(1), 151-166.

Ferreira, P. (2012). Is there a European convergence in HRM practices? A cluster analysis of the high-performance paradigm across $\quad 31 \quad$ countries. $\quad$ Retrieved from http://www.academia.edu/1819509/Is_there_a_European_convergence_in_HRM_practices_A_cluster_analysis_of_the_highperformance_paradigm_across_31_countries

Foss, N. J., \& Minbaeva, D. B. (2009). Governing knowledge: The strategic human resource management dimension. SMG Working Paper, No.3/2009, Copenhagen Business School, Denmark.

Freed, A., Hyatt, J., Papachristou, A., \& Papalexandris, N. (2012). Greek HRM: Building the critical competencies. Retrieved form http://www.rbl.net

Gooderham, P., Parry, E., \& Ringdal, K. (2008). The impact of bundles of strategic human resource management practices on the performance of European firms. The International Journal of Human Resource Management, 19(11), 2041-2056.

Hendry, C., \& Pettygrew, A. (1990). HRM: An agenda for the 1990s. International Journal of Human Resource Management, $1(1), 17-25$.

Huselid, M. A. (1995). Impact of HRM practices on turnover, productivity and corporate financial performance. Academy of Management, 38(3), 635-672.

Huselid, M. A., Jackson, S. E., \& Schuler, R. S. (1997). Technical and strategic human resource management effectiveness as determinants of firm performance. Academy of Management Journal, 40(1), 171-188.

Ignjatovic, M., \& Svetlik, I. (2003). European HRM clusters. EBS Review, 17, 25-39.

Jacobson, W. (2009). Is SHRM taking root in local governments? Proceedings from APSA 2009 Toronto Meeting Paper. Toronto, Canada.

Karoliny, Z., Farkas, F., \& Poor, J. (2009). In focus: Hungarian and central eastern European characteristics of human resource management: An international comparative survey. JEEMS, 1, 9-47. 
Katou, A. A., \& Budhwar, P. S. (2009). Causal relationship between HRM policies and organisational performance: Evidence from the Greek manufacturing sector. European Management Journal, 28(1), 25-39.

Kaufman, B. E. (2010). SHRM theory in the Post-Huselid Era: Why it is fundamentally misspecified. Industrial Relations, 49(2), 286-313.

Kunal, K., \& Kumar, A. (2011). Strategic human resource management content in the annual report of companies: An analysis through text mining. Indore Management Journal, 2(4), 15-26.

Lepak, D. P., \& Snell, S. A. (2002). Examining the HR architecture: The relationships among human capital, employment and human resource configurations. Journal of Management, 28(4), 517-543.

Liu, W., Lepak, D. P., Takeuchi, R., \& Sims, H. P. (2003). Matching leadership styles with employment modes: Strategic human resource management perspective. Human Resource Management Recview, 13, 127-152.

MacDuffie, J. P. (1995). Human resource bundles and manufacturing performance: Organizational logic and flexible production systems in the world auto industry. Industrial and Labor Relations Review, 48(2), 197-221.

Macfarlane, F., Greenhalgh, T., Humprey, C., Hughes, J., Butler, C., \& Ray, P. (2011). A new workforce in the making? A case study of strategic human resource management in a whole-system change effort in healthcare. Journal of Health Organization and Management, 25(1), 55-72.

Mesch, D. J., Perry, J. L., \& Wise, L. R. (1995). Bureaucratic and strategic human resource management: An empirical comparison in the Federal government. Journal of Public Administration Research and Theory, 5(4), 385-402.

Ngo, H. Y., Lau, C. M., \& Foley, S. (2008). Strategic human resource management, firm performance, and employee relations climate in China. Human Resource Management, 47(1), 73-90.

Othman, R. B. (1996). Strategic HRM: Evidence from the Irish food industry. Personnel Review, 25(1), 40-58.

Paauwe, J., \& Boselie, P. (2002). Challenging (strategic) human resource management theory: Integration of resource-based approaches and new institutionalism. Erasmus Institute of Management (ERS-2002-40-ORG), Erasmus University Rotterfan, Netherlands.

Pourkiani, M., Salajeghe, S., \& Ranjbar, M. (2011). Strategic human resource management and organizational knowledge creation capability. International Journal of e-Education, e-Management and e-Leraning, 1(5), 416-421.

Poutsma, E., Lighthart, P. E., \& Veersma, U. (2006). The diffusion of calculative and collaborative HRM practices in European firms. Industrial Relations, 45(4), 513-525.

Scholz, C., \& Müller, S. (2010). Human resource management in Europe: Looking again at the issue of convergence. Proceedings from 11th International Human Resource Management Conference, Birmingham, UK.

Schuler, R. S. (2000). The internationalization of human resource management. Journal of International Management, 6, $239-260$.

Schuler, R. S., \& Jackson, S. E. (1987). Linking competitive strategies with human resource management practices. Academy of Management Executive, 1(3), 207-219.

Simon, C. (2007). A case study approach to exploring the relationship between human resources management and firm performance. IE Working paper, WP07-01.

Simon, C., \& Martin, R. (2008). An implementation-based approach to SHRM: The concept of HR practice intensity and its relationship to individual performance. IE Business School Working Paper, WP08-19.

Snell, S. A. (1992). Control theory in strategic human resource management: Mediating effect of administrative information. Academy of Management Journal, 35(2), 292-327.

Sparrow, P. R., Brewster, C., \& Harris, H. (2004). Globalizing human resource management. London: Routledge.

Springer, B. (1995). US HRM and the EU social policy: A case study of the Works Council Directive. American Graduate School of International Management.

Stavrou, E., Brewster, C., \& Charalambous, C. (2004). Human resource management as a competitive tool in Europe. IIRA HRM Study Group Working Papers in Human Resource Management, No. 5.

Susilowati, Y., Hutagaol, P., Pasaribu, B., \& Djohar, S. (2012). The effectiveness of strategic human resource management in increasing firm performance in Indonesia. Proceedings from World Business and Economics Research Conference 2012. Yuniari Susilowati, Bogor.

Takei, H., \& Ho, Y. (2007). Human resource management and governance in the central and eastern Europe. 21st Century Center of Excellence Program, Policy and Governance Working Paper Series, No. 119.

Uysal, G. (2012). Taylor, HRM, strategic HRM with jobs, employee performance, business performance relationship: HR governance through 100 years. Journal of Business and Economics, 3(4), 279-284. 
Weatherly, L. A. (2003). The value of people: The challenges and opportunities of human capital measurement and reporting. Society for Human Resource Management, SHRM Research Paper.

Wright, P. M., \& McMahan, G. C. (1992). Theoretical perspectives for strategic human resource management. Journal of Management, 18(2), 295-320.

Wright, P. M., Gardner, T. M., \& Moynihan, L. M. (2003). The impact of HR practices on the performance of business units. Human Resource Management Journal, 13(3), 21-36.

Zupan, N., \& Kase, R. (2005). Strategic human resource management in European transition economies: Building a conceptual model on the case of Slovenia. International Journal of Human resource Management, 16(6), 882-906. 